\title{
HOME BASED EXERCISE TRAINING (HBET) DAPAT MENINGKATKAN KAPASITAS FUNGSIONAL PASIEN GAGAL JANTUNG
}

\author{
Ni Kadek Yuni Lestari \\ STIKes Wira Medika Bali \\ Email : yunilestariwika@gmail.com
}

\begin{abstract}
ABSTRAK
Pendahuluan: Latihan fisik untuk meningkatkan kapasitas fungsional pada penderita gagal jantung masih belum mendapatkan perhatian khusus dari petugas kesehatan. Kapasitas fungsional yang menurun berdampak pada penurunan kemampuan pasien dalam melakukan aktivitas sehari-hari. Tujuan penelitian : menganalisis peningkatan kapasitas fungsional setelah diberikan home based exercise training pada pasien gagal jantung. Metode: desain penelitian pra-eksperimen yaitu one group pretest-posttest design. Teknik sampling yang digunakan adalah purposive sampling, didapatkan 10 responden. Peneliti menggunakan teknik $6 M W T$ untuk mengumpulkan data kapasitas fungsional. Hasil : analisa data dilakukan dengan menggunakan uji paired t test. Hasil analisa dapat diperoleh nilai $p=0,001(\alpha=0,05)$. Berdasarkan hasil penelitian menunjukkan kapasitas fungsional sebelum diberikan latihan adalah $245 \mathrm{~m}$ dan setelah perlakuan sebesar $255 \mathrm{~m}$. Diskusi: latihan fisik secara bertahap menyebabkan peningkatan daya pompa ventrikel sehingga terjadi peningkatan kapasitas fungsional. HBET dapat digunakan sebagai terapi modalitas keperawatan untuk meningkatkan kapasitas fungsional pasien gagal jantung setelah perawatan di rumah sakit.
\end{abstract}

Kata kunci : Home Based Exercise Training (HBET), Peningkatan Kapasitas Fungsional, Gagal Jantung

\section{HOME BASED EXERCISE TRAINING CAN INCREASE FUNCTIONAL CAPACITY OF PATIENT WITH HEART FAILURE IN RSUD BADUNG}

\begin{abstract}
Backround: Physical exercise to increase functional capacity in people with heart failure has not received special attention from the health workers. Decreased functional capacity has an impact on reducing the patient's ability to carry out daily activities. Purpose: to analyze the increase in functional capacity after being given home based exercise training in patients with heart failure. Method: the research design used was pre-experimental, One Group Pretest-Post Test Design. The sampling technique used was purposive sampling, obtained 10 respondents. Functional capacity data collection is done by 6MWT. Results: data analysis was performed using paired t test. The results of the analysis can be obtained $p=0.001(\alpha=0.05)$. The measurement results obtained a significant difference in functional capacity before $(245 \mathrm{~m})$ and $(255 \mathrm{~m})$ after treatment. Discussion: Physical exercise gradually causes an increase in the ventricular pumping power of the heart to increase functional capacity. HBET can be used as a nursing modality therapy to increase the functional capacity of heart failure patients after hospitalization
\end{abstract}


Keywords : Home Based Exercise Training (HBET), Increase Functional Capacity, Heart Failure.

\section{PENDAHULUAN}

Meningkatkanya angka prevalensi gagal jantung di dunia maupun di Indonesia menjadai masalah yang perlu diperhatikan. Sebesar 5,7 juta penduduk dunia menderita gagal jantung pada tahun 2013 dan mengalami peningkatan yang drastis menjadi 9,5 juta pada tahun 2014 dan mencapai angka 17,3 juta pada tahun 2015. ${ }^{1}$ Sedangkan di Indonesia terjadi peningkatan dengan jumlah 182.344 penderita tahun 2013 menjadi 229.696 pada tahun $2014 .^{2}$

Pasien gagal jantung sering mengalami gejala seperti sesak nafas, cepat lelah dan tidak bisa menjalani aktivitas fisik yang berat. Hal tersebut berdampak pada penurunan kemampuan untuk beraktifitas sehingga kapasitas fungsional tidak menurun. ${ }^{3}$ Kapasitas fungsional adalah kemampuan individu dalam pemenuhan kebutuhan sktivitas sehari-hari. Upaya untuk meningkatkan kapasitas fungsional adalah dengan latihan fisik. Latihan fisik yang dimaksud berpedoman pada tipe latihan, intensitas atau seberapa sering latihan fisik tersebut dilakukan, lamanya latihan, dan frekuensi latihan. Jenis latihan yang aman dilakukan pada pasien gagal jantung stabil yaitu latihan aerobik selama 20-30 menit dimana latihan tersebut aman dilakukan tiga kali seminggu dengan intensitas latihan sebesar 40-60\% dari denyut jantung maksimal. ${ }^{4}$

Latihan fisik penderita gagal jantung belum mendapatkan perhatian yang memadai seperti pada infark miokard dan penyakit jantung koroner. Berdasarkan beberapa penelitian yang pernah dilakukan bahwa latihan fisik bisa dilakukan dan sangat bermanfaat bagi pasien gagal jantung dalam keadaan stabil. Hal tersebut bertolak belakang dengan fenomena yang terjadi yaitu tingkat partisipasi dan pelaksanaannya masih rendah. Hal tersebut bisa disebabkan karena biaya dan kurangnya pemahaman masyarakat terkait manfaat latihan yang dilakukan. ${ }^{4}$

Home Based Exercise Training (HBET) merupakan jenis pelatihan untuk meningkatkan kapasitas fungsional pada pasien gagal jantung stabil. HBET adalah sebuah program pelatihan fisik yang dengan mudah bisa dilakukan oleh pasien setelah perawatan di rumah sakit. Penelitian Coats (1990) didapatkan setelah diberikan latihan fisik HBET konsumsi oksigen maksimal menjadi meningkat sebesar $17 \%$, diikuti oleh peningkatan durasi latihan dan peningkatan kualitas hidup sebesar 18\%. Adapun kelebihan latihan fisik HBET yaitu dapat dilakukan dimana saja tanpa harus mengeluarkan biaya tambahan. ${ }^{5}$ Instrumen pengumpulan data dalam penelitian ini berupa check list six minute walk test (6MWT) untuk mengukur kapasitas fungsional. Six minute walk test mempunyai akurasi antara 83\% sampai $91 \%$ untuk memprediksi $\mathrm{VO}_{2} \max$, jika hasil 6MWT antara 450-490 meter. Terdapat korelasi yang kuat jika pasien mempunyai hasil $6 M W T<300$ meter atau konsumsi oksigen maksimal rendah $(<10 \mathrm{~mL} / \mathrm{kg} / \mathrm{min})^{11}$.

\section{METODE}

Desain pra eksperimen One Group Pretest-Posttest Design merupakan desain yang digunakan dalam penelitian ini. Adapun populasinya adalah seluruh pasien gagal jantung di RSUD Badung. Pemilihan sampel dengan non probability yaitu purposive sampling $^{6}$. Adapun sampel yang dipilih sesuai dengan kriteria inklusi yaitu pasien gagal jantung dengan klasifikasi kelas I dan II stabil yang ditandai dengan tidak ada nyeri dada, tidak sesak napas saat istirahat, denyut nadi istirahat 60-100 $\mathrm{x} / \mathrm{mnt}$ dan reguler, tekanan darah sistolik 100-150 mmHg dan diastolik 60-90 mmHg. Peneliti menggunakan jumlah sampel minimal sebanyak 10 orang. Jumlah 
sampel untuk jenis penelitian eksperimen yang sederhana antara 10 sampai dengan 20 orang ${ }^{6}$.

Pemberian intervensi Home Based Exercise Training (HBET) dilakukan pada bulan Mei - Juni sebanyak 12 kali dengan rincian tiga kali seminggu selama 30 menit untuk setiap kali latihan. Intensitas latihan yang diberikan yaitu 40-60\% dari denyut nadi maksimal. Pemantauan latihan dilakukan oleh peneliti sendiri dibantu oleh enumerator yaitu perawat yang bekerja di Poliklinik Jantung menggunakan SOP HBET. Sebelum diberikan pelatihan HBET dilakukan pengukuran kapasitas fungsional di rumah pasien masingmasing. Setelah pemberian pelatihan selama 12 kali dilakukan pengukuran kembali sebagai nilai post-test.

\section{HASIL PENELITIAN}

Tabel 1.

Karakteristik Responden Berdasarkan Jenis Kelamin

\begin{tabular}{lcr}
\hline Jenis kelamin & Frekuensi & Persentase \\
\hline Laki-laki & 4 & $40 \%$ \\
Perempuan & 6 & $60 \%$ \\
\hline Total & 10 & $100 \%$ \\
\hline
\end{tabular}

Berdasarkan tabel 1 sebanyak 6 responden $(60 \%)$ dengan jenis kelamin peempuan.

Tabel 2.

Distribusi frekuensi responden berdasarkan usia

\begin{tabular}{ccc}
\hline Usia & Frekuensi & Persentase \\
\hline$<65$ tahun & 3 & $30 \%$ \\
$>65$ tahun & 7 & $70 \%$ \\
\hline Total & 10 & $100 \%$ \\
\hline
\end{tabular}

Berdasarkan tabel diatas menunjukkan bahwa responden yang berusia $>65$ tahun sebanyak 7 responden (70\%) sedangkan yang berusia $<65$ tahun sebanyak 3 orang (30\%).
Tabel 3.

Distribusi frekuensi responden berdasarkan IMT

\begin{tabular}{ccc}
\hline IMT & Frekuensi & Persentase \\
\hline Obesitas & 6 & $60 \%$ \\
Normal & 4 & $40 \%$ \\
\hline Total & 10 & $100 \%$ \\
\hline
\end{tabular}

Hasil penelitian menunjukkan responden yang obesitas sebanyak 6 responden $(60 \%)$ dan yang memiliki IMT normal sebanyak 4 orang (40\%).

\section{Tabel 4.}

Kapasitas fungsional sebelum diberikan HBET

\begin{tabular}{llll}
\hline Variabel & Mean & SD & Min-mak \\
\hline $\begin{array}{l}\text { Kapasitas } \\
\text { fungsional }\end{array}$ & 279,72 & 22,32 & $245-309$ \\
\hline
\end{tabular}

Berdasarkan tabel diatas menunjukkan bahwa rata-rata kapasitas fungsional sebelum diberikan HBET adalah 279,72 meter $(\mathrm{SD}=22,32)$. Dapat disimpulkan bahwa nilai minimal kapasitas fungsional sebesar 245 meter dan nilai maksimal kapasitas fungsional sebesar 309 meter.

Tabel 5.

Kapasitas fungsional setelah diberikan HBET

\begin{tabular}{llll}
\hline Variabel & Mean & SD & Min-mak \\
\hline $\begin{array}{l}\text { Kapasitas } \\
\text { fungsional }\end{array}$ & 292,86 & 21,82 & $255-324$ \\
\hline
\end{tabular}

Berdasarkan tabel diatas menunjukkan bahwa rata-rata kapasitas fungsional setelah diberikan HBET adalah adalah 292,86 meter $(\mathrm{SD}=21,82)$. Nilai minimal kapasitas fungsional sebesar 255 meter dan nilai maksimal kapasitas fungsional sebesar 324 meter. 
Tabel 6.

Analisis perbedaan kapasitas fungsional sebelum dan sesudah HBET

Hasil analisis uji statistik paired t-test dengan bantuan media komputer pada setiap variabel sebelum dan setelah diberikan HBET diperoleh tingkat kemaknaan $\alpha=0,05$ dimana nilai $\mathrm{p}$ yang diperoleh sebesar 0,001 sehingga kesimpulan penelitiannya $\mathrm{H}_{0}$ ditolak dan $\mathrm{H}_{1}$ diterima. Hal ini menunjukkan adanya pengaruh HBET terhadap kapasitas fungsional pasien gagal jantung.

\section{PEMBAHASAN}

\section{Home Based Exercise Training (HBET) dapat meningkatkan kapasitas fungsional pasien gagal jantung.}

Rata-rata kapasitas fungsional responden mengalami peningkatan 13,14 meter bila dibandingkan dengan pengukuran sebelum melakukan HBET. Hal ini berarti responden mengalami peningkatan kemampuan fungsional bila dibandingkan dengan pengukuran sebelumnya. Kondisi ini terjadi karena membaiknya fungsi pompa otot jantung karena managemen gagal jantung yang adekuat dan latihan fisik dengan HBET yang dilakukan secara teratur. Kombinasi antara terapi farmakologis, edukasi perubahan gaya hidup dan latihan fisik di rumah dengan HBET ini efektif untuk mempertahankan bahkan dapat meningkatkan kemampuan pompa ventrikel kiri. Hasil paired $t$ test $\mathrm{p}$ value $=0,001 \quad(<0,05)$ yang berarti terdapat perbedaan yang signifikan kapasitas fungsional sebelum dengan sesudah mendapatkan HBET selama 4 minggu.

McKelvie (2008) menyatakan peningkatan kualitas hidup dapat dicapai dengan melakukan latihan fisik secara rutin dan berkelanjutan. Kesembuhan pasien dapat dicapai dengan rutin melakukan latihan fisik. Manfaat yang didapatkan setelah melakukan sebuah pelatihan fisik adalah dapat meningkatkan toleransi latihan serta mempercepat proses kesembuhan bagi pasien. Peningkatan kapasitas fungsional dapat tercaai dengan melakukan home based

\begin{tabular}{llllll}
\hline \multicolumn{1}{c}{ Variabel } & & Mean & SD & p & $n$ \\
\hline $\begin{array}{l}\text { Kapasitas } \\
\text { fungsional }\end{array}$ & Pre- & 279,72 & 22,32 & 0,0 & 10 \\
& Post & 292,86 & 21,82 & $01^{*}$ &
\end{tabular}

exercise training. Pelatihan tersebut juga bermanfaat dalam menstabilkan berat badan, meningkatkan kapasitas oksidasi otot skeletal, memperbaiki kontrol syaraf otonom dan pembuluh darah. ${ }^{8}$

Latihan fisik dapat meningkatkan kapasitas fungsional yang berdampak pada perubahan fisiologis, psikologis dan muskuloskeletal. Sebuah pelatihan fisik yang dilakukan oleh penderita gagal jantung stabil dapat meningkatkan adaptasi fisiologis dari otot-otot yang dilatih, menstimulasi pengeluaran enzim aerobic serta nitrit oxide. Hal tersebut mengakibatkan penurunan tahanan pembuluh darah perifer serta memperbaiki volume darah yang dipompa oleh jantung. Hal tersebut bisa didapatkan melalui pelatihan HBET .

Saat melakukan HBET, kebutuhan metabolik jaringan tubuh meningkat. Pada saat yang sama kebutuhan oksigen dan nutrisi untuk jaringan juga mengalami peningkatan dan di sisi lain banyak karbondioksida, toksin, dan produk lain yang tidak diperlukan dibuang. Pada orang sehat kondisi ini dikompensasi dengan peningkatan cardiac output bisa sampai 6 kali lipat dalam kondisi istirahat. Latihan fisik ini mencapai puncaknya pada kondisi maximal oxigen uptake $\left(\mathrm{VC}_{2} \mathrm{max}\right)$. Pada saat $\mathrm{VC}_{2} \mathrm{max}$ mencapai 80-90\%, maka karbondioksida akan dibentuk secara berlebihan sehingga terjadi metabolisme otot anaerob dan peningkatan produksi asam laktat yang menghasilkan kelelahan berlebih. Latihan HBET yang dilakukan pada pasien gagal jantung stabil secara bertahap dapat meningkatkan kemampuan ventrikel jantung untuk 
memenuhi kebutuhan nutrisi dan oksigen jaringan sehingga terjadi peningkatan kapasitas fungsional. ${ }^{10}$

$$
\text { Peningkatan kapasitas fungsional }
$$
setelah diberikan pelatihan home based exercise training (HBET) pada pasien gagal jantung dipengaruhi oleh frekuensi, intensitas, durasi dan mode latihan fisik. Selain itu setiap responden memiliki kemampuan untuk meningkatkan perawatan diri secara mandiri. Dukungan keluarga dan teman dekat sangat diperlukan untuk membangun kepercayaan diri yang positif dan meningkatkan kemampuan self care pasien. Adapun keterbatasan dalam penelitian ini adalah peneliti tidak memisahkan klasifikasi gagal jantung kelas I dan II sehingga tidak bisa dibedakan yang mengalami perubahan kapasitas fungsional secara signifikan, peneliti tidak dapat mengontrol aktivitas fisik lain yang dilakukan responden yang dapat mempengaruhi efek terapi HBET serta pengkategorian IMT responden yang tidak homogen.

\section{SIMPULAN}

1. Nilai rata-rata kapasitas fungsional sebelum diberikan terapi home based exercise training (HBET) adalah 279,72 meter $(\mathrm{SD}=22,32)$.

2. Nilai rata-rata kapasitas fungsional setelah diberikan terapi home based exercise training (HBET) adalah 292,86 meter $(\mathrm{SD}=21,82)$.

3. Kapasitas fungsional mengalami peningkatan rata-rata 13,14 meter bila dibandingkan dengan pengukuran sebelum diberikan terapi HBET. Hasil uji statistik dengan Paired T-test diperoleh nilai $p$-value sebesar 0,001 sehingga $p$ value $<\alpha(0,05)$ maka pemberian terapi home based exercise training (HBET) mampu meningkatkan kapasitas fungsional pada pasien gagal jantung.

\section{SARAN}

Berdasarkan hasil penelitian diatas dapat digunakan sebagai salah satu dasar pengembangan evidence based nursing untuk mendapatkan intervensi mandiri keperawatan yang terbukti efektif dan aman dilakukan pada pasien gagal jantung. HBET dapat juga dimasukkan dalam program rehabilitasi pasien gagal jantung di rumah sakit. Keluarga dan pasien diharapkan dapat menjadikan penelitian ini sebagai pedoman dan dapat memotivasi pasien untuk patuh terhadap terapi yang dijalankan baik di rumah sakit maupun dirumah.

\section{DAFTAR PUSTAKA}

1. American Heart Association (AHA). 2015. Metabolic risk for cardiovascular disease edited by Robert H. Eckel. Wiley - Blackwell Publishing.

2. Riset Kesehatan Dasar (Riskesdas). 2013. Laporan Nasional. Jakarta: Badan Litbangkes Depkes.

3. Black \& Hawks. 2009. Medical Surgical Nursing Clinical Mnagement for Positive Outcomes. elseveir Saunders.

4. Nicholson, C. 2007. Heart failure, A clinical nursing handbook. John Wiley \& Sons. Ltd.

5. Coats AJ, Adamopoules S, Meyer TE, Counray J, Slight P. 1990. Effects of physical training in chronic heart failure. Lancet. 335: 63-68.

6. Sugiyono, Dr. 2014. Metode penelitian Kuantitatif Kualitatif dan $R \& D$, Penerbit ALFABETA

7. American Collage of Sport Medicine. 2006. Guidelines for Exercise Testing and Exercise Prescription, 7 th ed. Lippincot, Williams and Wilkins, Baltimore.

8. McKelvie RS. 2008. Exercise Training in patient with heart failure: 
Clinical outcome, safety, and indication. Heart Fail Rev. 13:3-11

9. Nicholson, C. 2007. Heart failure, A clinical nursing handbook. John Wiley \& Sons. Ltd.

10. Kusmana, D. 2006. Olah raga untuk orang sehat dan penderita penyakit jantung. Edisi kedua. BP FKUI. Jakarta.

11. American Thoracic Society. 2002. ATS statement: Guidelines For The Six-Minute Walk Test. Am J Respir Crit Care Med. 